\title{
Rectal Involvement of Klippel-Trenaunay Syndrome
}

\author{
Seong-Hui Cheon, M.D., Suk-Hwan Lee, M.D. ${ }^{1}$, Eung-Bum Park, M.D. \\ Department of Surgery, Ewha Womans University College of Medicine, Seoul; 'Department of Surgery, Kyunghee University College of Medicine, \\ Seoul, Korea
}

Klippel-Trenaunay syndrome (KTS) is a rare congenital disorder and is essentially a disorder of capillary, venous, and lymphatic malformations. Hematochezia is the most common symptom associated with intestinal hemangiomatosis and remains one of the life-threatening emergencies in KTS. We reported one patient of KTS presented with rectal bleeding and severe anemia who was successfully managed by sphincter-saving operation.

Keywords: Rectal bleeding; Klippel-Trenaunay syndrome; Coloanal anastomosis

\section{INTRODUCTION}

Klippel-Trenaunay syndrome (KTS) is characterized by the triad of vascular nevi, venous varicosity, and hyperplasia of soft tissue and bone in the affected area. Klippel and Trenaunay reported the first case in $1900 .{ }^{1}$ The syndrome is currently defined by the combination of at least two of the above clinical features. The original description was made with regard to the extremities. KTS is a disorder of capillary, venous, and lymphatic malformations and the absence of arteriovenous fistulas distinguishes KTS from the Parkes Weber syndrome. Hematochezia is the most common symptom associated with intestinal hemangiomatosis and remains one of the life-threatening emergencies in KTS. ${ }^{2,3}$ In the following case report, we describe a patient who presented with anemia, rectal bleeding and history of recurrent varicoceles and review the literatures on the visceral involvement of KTS.

\section{REPORT OF A CASE}

A 16-yr-old boy was presented with hematochezia and dyspnea

Received: January 7, 2008 Accepted: August 19, 2008 Correspondence to : Suk-Hwan Lee, M.D.

Department of Surgery, Kyunghee University Neo-medical Center, 149 Sangil-dong, Gangdong-gu, Seoul 134-727, Korea

Tel : +82.2-440-6134, Fax : +82.2-440-6295

E-mail : leeshdr@khu.ac.kr

*Poster presented at the Annual Spring Meeting of Korean Surgical Society on May 10, 2002 at Kyung-Ju, Kyungsangbuk-Do, Korea.

(C)2009 The Korean Society of Coloproctology on exertion to the emergency room. He had noticed intermittent hematochezia and protruding anal mass on defecation since last two years and dyspnea on exertion developed about 6 mo ago.

His past medical history was significant for a large hemangioma on the left lower extremity since birth. He had undergone multiple operations for undescended testis and varicoceles from age 8 to 15. The diagnosis of KTS was made at the time of the first operation when he was 8 yr old. He had noticed intermittent leg pain for the previous 6 yr.

On physical examination, he showed limping gate and an asymmetric, edematous hypertrophy, cutaneous varicosity and port wine stain along the lateral aspect of the left lower extremity (Fig. 1). Anal inspection revealed third degree internal hemorrhoids and digital rectal examination showed bright red blood on the glove.

Laboratory evaluation demonstrated significant anemia with hemoglobin of $6.4 \mathrm{~g} / \mathrm{dL}$ and the hematocrit of $20.8 \%$. Platelet count and coagulation parameters were normal.

Gastroscopy was negative for portal hypertensive gastropathy or esophageal varices. Diagnostic colonoscopy and transrectal ultrasonography revealed presence of numerous severely dilated and engorged blood vessels in the submucosal layer in the rectum and distal sigmoid colon (Fig. 2, 3). Remainder of colon was normal. Preoperative visceral angiography had revealed no additional vascular malformations in the major abdominal vasculature. Four units of packed red blood cell were administrated and oral iron supplements were started. Resection of distal sigmoid colon and 


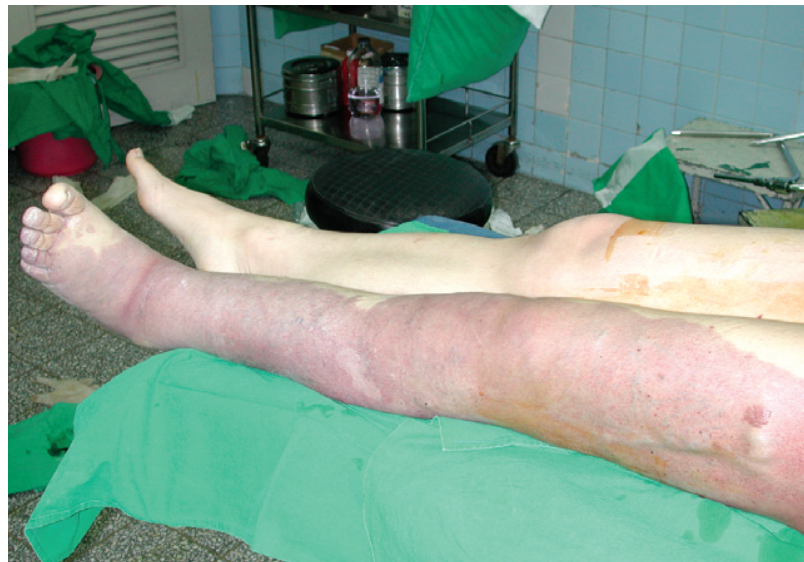

Fig. 1. An asymmetric, edematous hypertrophy of left lower extremity, cutaneous varicosity and port-wine stain along the lateral aspect of hypertrophied left lower extremity as typically seen in KTS.

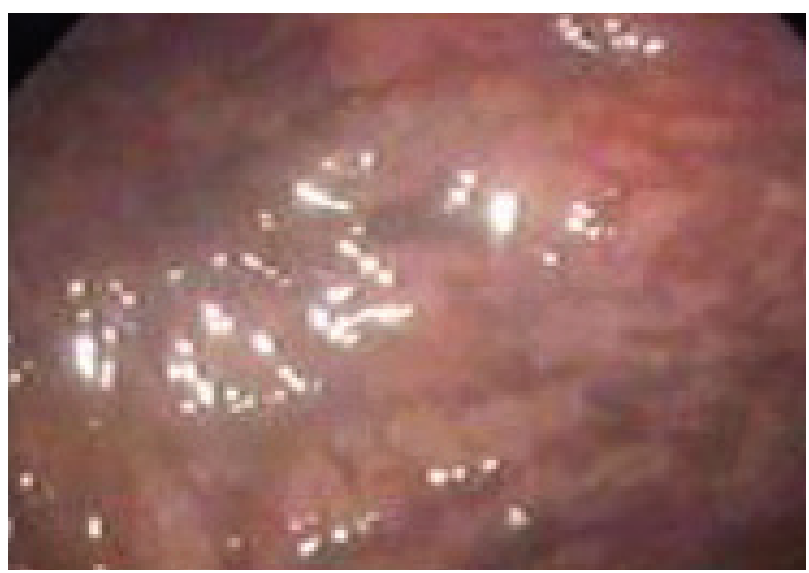

Fig. 2. Colonoscopic findings. Numerous engorged vessels were noted on the bowel wall of the rectum and distal sigmoid colon.

rectum were performed and then the proximal sigmoid colon was anastomosed to the anorectal ring by the double stapling technique. Operative finding confirmed the vascular malformation with severely dilated and engorged veins of bowel wall along the distal sigmoid colon and entire rectum (Fig. 4). The postoperative course was uneventful and he was discharged on postoperative day 12. On the last follow-up examination 35 mo after surgery, he remained asymptomatic without signs of further rectal bleeding.

\section{DISCUSSION}

Since KTS is a congenital disorder of capillary, venous and lymphatic systems, rectal bleeding from the engorged vessels has been reported to occur in 1-12\% of patients. ${ }^{4,5}$ Gastrointes-

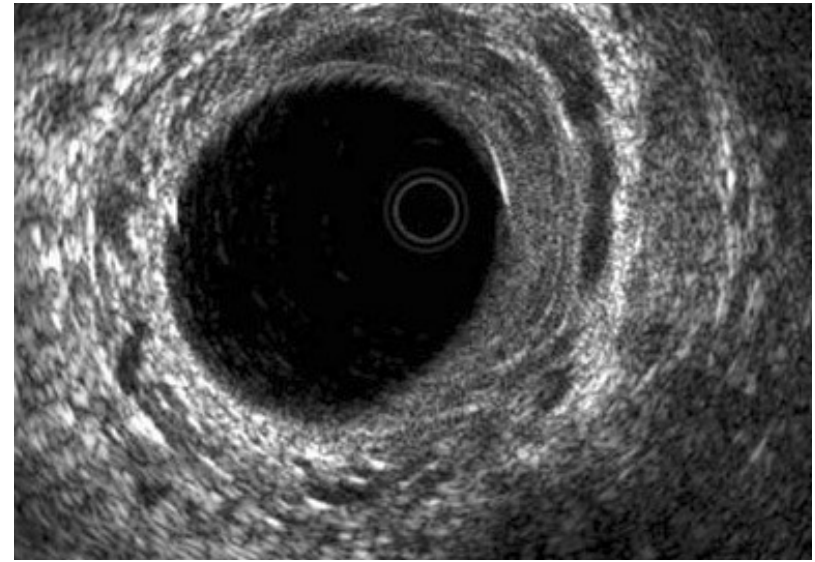

Fig. 3. Transrectal ultrasonography showed numerous severely dilated and engorged blood vessels of submucosal and muscular layer in the rectum.

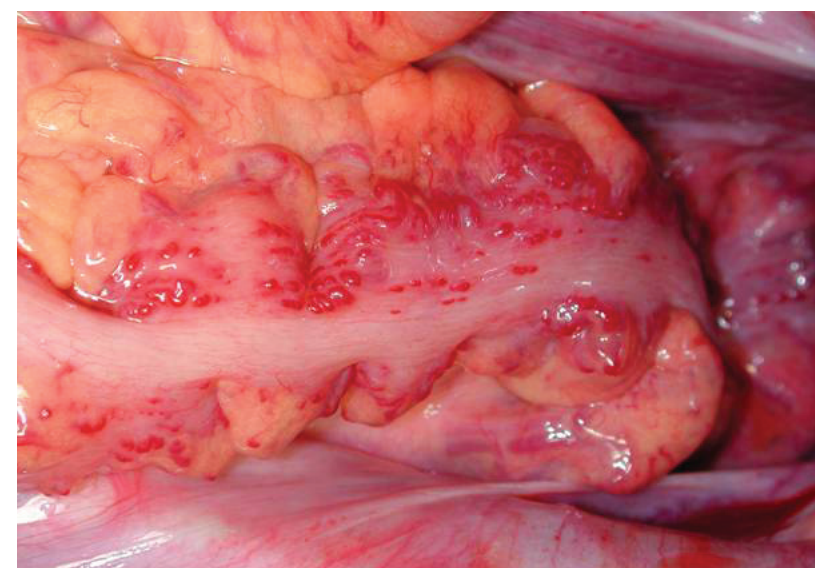

Fig. 4. Operative finding shows severely dilated, engorged vessels along the distal sigmoid colon and the rectum.

tinal (GI) bleeding usually begins in the first decade of life and tends to be intermittent in nature. ${ }^{4,6}$ In addition to hematochezia due to colorectal involvement, other visceral manifestations of KTS that have been reported, include lower GI bleeding due to small bowel varicosities, upper GI bleeding due to esophageal variceal hemorrhage due to cavenous transformation of hypoplasia of the portal vein. ${ }^{7,8}$ Although rare, other viscera may be involved in KTS, including the spleen, lung, heart, liver and kidney. ${ }^{9-13}$ Moreover, GI bleeding from the visceral involvement remains one of the potentially life-threatening emergencies in KTS.

Endoscopy and selective visceral angiography remain the most useful diagnostic procedures to detect and determine the extent of these GI involvement. And in cases of atypical presentation of KTS, the ultrasound with color Doppler and duplex scanning 
are very useful to establish the diagnosis. ${ }^{14}$

Management of colorectal intestinal involvement in KTS will depend on extent and severity of bleeding. Although conservative managements and iron supplements for iron deficiency anemia may be sufficient in the patient who presents with occasionally non-significant bleeding, it is unlikely to be effective in the long term in view of the diffuse and progressive disease process. Transfusion dependency, life-threatening bleeding episodes, and poor quality of life require definitive therapy.

Conservative managements such as endoscopic therapy with sclerosis, band ligation, and laser are usually ineffective due to the extensive nature of the lesion. Endoscopic lasers have been used effectively to treat vascular lesions in children due to the mortality and morbidity associated with surgery. ${ }^{2,15}$ The use of endoscopic laser therapy for extensive vascular lesions is only palliative measure but not curative. Thus, endoscopic laser therapy is best used for ablation of localized lesions of postoperative residual lesions.

Resection of the involved bowel segment is usually necessary to adequately control bleeding and life-saving. Rectal involvement of KTS has usually been treated with an abdominoperineal resection of the involved segment and permanent colostomy or resection of the involved segment with colostomy. But considering that most patients are young patients and disfiguring nature of the syndrome (hypertrophy of the extremity or port-wine stain), lower anterior resection with restoration of anal function by coloanal anastomosis must be considered if no extensive perianal involvement exists. Telander et al. have reported the success of segmental colonic resection, rectal mucosectomy, and coloanal anastomosis in patients with recurrent rectal bleeding. ${ }^{16}$

Our case showed classic triad of KTS and successfully managed by the lower anterior resection and coloanal anastomosis. To the best of our knowledge, this case report is the first one in Korean literature to treat the KTS with lower anterior resection.

Although KTS is a rare disease causing lower gastrointestinal tract bleeding, one should be aware of the disease entity and proper management to save the patient and to improve the patient's quality of life after the operation.

\section{REFERENCES}

1. Klippel M, Trenaunay P. Du Naevus variqueux osteohypertrophique.
Arch Gen Med 1900;185:641-72.

2. Azizkhan RG. Life-threatening hematochezia from a rectosigmoid vascular malformation in Klippel-Trenaunay syndrome: long-term palliation using an argon laser. J Pediatr Surg 1991;26:1125-7.

3. Wilson CL, Song LM, Chua H, Ferrara M, Devine RM, Dozois RR, et al. Bleeding from cavernous angiomatosis of the rectum in KlippelTrenaunay syndrome: report of three cases and literature review. Am J Gastroenterol 2001;96:2783-8.

4. Servelle M, Bastin R, Loygue J, Montagnani A, Bacour F, Soulie J, et al. Hematuria and rectal bleeding in the child with Klippel and Trenaunay syndrome. Ann Surg 1976;183:418-28.

5. Jacob AG, Driscoll DJ, Shaughnessy WJ, Stanson AW, Clay RP, Gloviczki P. Klippel-Trenaunay syndrome: spectrum and management. Mayo Clin Proc 1998;73:28-36.

6. Ghahremani GG, Kangarloo H, Volberg F, Meyers MA. Diffuse cavernous hemangioma of the colon in the Klippel-Trenaunay syndrome. Radiology 1976;118:673-8.

7. Brown R, Ohri SK, Ghosh P, Jackson J, Spencer J, Allison D. Case report: jejunal vascular malformation in Klippel-Trenaunay syndrome. Clin Radiol 1991;44:134-6.

8. Bataller R, Sans M, Escorsell A, Elizalde JI, Bosch J, Rodes J. Esophageal variceal bleeding caused by hypoplasia of the portal vein in a patient with the Klippel-Trenaunay syndrome. Am J Gastroenterol 1998; 93:275-6.

9. Hamano K, Hiraoka H, Kouchi Y, Fujioka K, Esato K. Klippel-Trenaunay syndrome associated with splenomegaly: report of a case. Surg Today 1995;25:272-4.

10. Joshi M, Cole S, Knibbs D, Diana D. Pulmonary abnormalities in Klippel-Trenaunay syndrome. A histologic, ultrastructural, and immunocytochemical study. Chest 1992;102:1274-7.

11. Drose JA, Thickman D, Wiggins J, Haverkamp AB. Fetal echocardiographic findings in the Klippel-Trenaunay-Weber syndrome. J Ultrasound Med 1991;10:525-7.

12. Bathgate A, MacGilchrist A, Piris J, Garden J. Multiple focal nodular hyperplasia in Klippel-Trenaunay syndrome. Gastroenterology 1999; 117:284-5.

13. Fligelstone LJ, Campbell F, Ray DK, Rees RW. The Klippel-Trenaunay syndrome: a rare cause of hematuria requiring nephrectomy. J Urol 1994;151:404-5.

14. Vazquez-Sequeiros E, Sorbi D, Kamath PS, Wiersema MJ. KlippelTrenaunay-Weber syndrome: role of EUS. Gastrointest Endosc 2001; 
54:660-1.

15. Myers BM. Treatment of colonic bleeding in Klippel-Trenaunay syndrome with combined partial colectomy and endoscopic laser. Dig Dis Sci 1993;38:1351-3.

16. Telander RL, Ahlquist D, Blaufuss MC. Rectal mucosectomy: a definitive approach to extensive hemangiomas of the rectum. J Pediatr Surg $1993 ; 28: 379-81$.

\section{국문 초록}

\section{Klippel-Trenaunay Syndreme의 직장 병변}

천승희 · 이석환 ${ }^{1} \cdot$ 박응범

이화여자대학교 의과대학 외과학교실, ${ }^{1}$ 경희대학교 의과대학 외과학교실

Klippel-Trenaunay syndrome (KTS)은 매우 희귀한 선 천성 질환으로 주로는 혈관질환으로 나타난다.

$\mathrm{KTS}$ 의 소화기관 침범 역시 흔하지 않지만 소화기관 침범한 경우에는 직장출혈이 가장 흔한 증상이며, 생명을 위협하는 경우도 있다. 저자들은 만성 직장출혈에 의한 빈혈을 주소로 내원한 16 세 남자에게서 KTS를 진단하고 항문 괄약근 보존 술식으로 치료하였기에 문헌 고찰과 함께 보고하는 바이다.

중심단어: 직장 출혈, Klippel-Trenaunay 증후군, 결장항문문합술 